\title{
The Analysis of Inflation Rate Dynamic in Central and South-Eastern Europe's States in the Context of The EU Accession
}

\author{
Ovidiu Stoica ${ }^{1} \&$ Monica Damian ${ }^{2}$ \\ ${ }^{1}$ Department of Finance, Money and Public Administration, "Alexandru Ioan Cuza" University of Iasi, Romania \\ ${ }^{2}$ Department of Finance, Money and Banking, "Alexandru Ioan Cuza" University of Iasi, Romania \\ Correspondence: Ovidiu Stoica, Department of Finance, Money and Public Administration, "Alexandru Ioan \\ Cuza" University of Iasi, Romania.
}

Received: November 9, 2012

Accepted: December 27, $2012 \quad$ Online Published: January 11, 2013

doi:10.5539/ijef.v5n2p102

URL: http://dx.doi.org/10.5539/ijef.v5n2p102

\begin{abstract}
In the year 2004 ten states from Central and South-Eastern Europe joined the European Union. The majority of them have registered a significant consumer price increase in the year 2004. The goal of this paper is to examine the fundamental factors that have influenced inflation rate after EU accession and to analyse the causes of the inflation differential in EU member states which acceded in 2004. The impact of EU accession was different in analysed countries, the increasing of inflation rate in accession year being determined by the adoption of the Common Agricultural Policy, the harmonization of the structure and rates of indirect taxes, the introduction of the Common Customs Policy, the free movement of goods, the free movement of capital and the expected inflation.

From the analyses we have done, we have remarked that the main cause of inflation differential has been the oil price on the international market, because of the different degree of dependence on oil import of these countries, but also on the different weight of electricity, gases and other fuels in the consumer basket.
\end{abstract}

Keywords: European Union accession, inflation rate, inflation differential, causes, Central and South-Eastern Europe

\section{Introduction}

Following the rapid change of the political systems and the restructuration process of the economies, the countries from Central and Eastern Europe have begun the political and economic integration with the European Union. These countries have expressed their wish to accede to the European Union and realign their economies towards the West. Some of them have managed to attract important sums of foreign direct investments, most of which coming from the member states of the European Union. The European Union has supported this process through the conclusion of the European Agreements, which gave the institutional framework for the future integration, in terms of trade and other economic relations.

The European Council in Copenhagen in June the 22nd and 23rd 1993 agreed that the associated countries from Central and Eastern Europe who wish and satisfy the required political and economic conditions will become members of the European Union.

At the reunion of the European Council in Copenhagen in December 2002, the EU enlargement was decided with ten states, such as: Cyprus, the Czech Republic, Estonia, Hungary, Latvia, Lithuania, Malta, Poland, Slovakia and Slovenia. The decision to expand the European Union is an important step towards modelling of the future political, institutional and economical structures of Europe.

From a macroeconomic point of view, the enlargement of the European Union is a "profitable investment", because it has positive effects both on the economies of the new member states, and the European Union as a whole, especially, in the registration of high economic growth rates.

Inflation is extremely important, according to the political agenda of the EU, as can be seen from the main conclusions reached at the Helsinki seminar (1999): Accession countries therefore need to continue to implement monetary policies geared towards achieving and maintaining price stability, and to support this process with prudent fiscal policies and adequate structural reforms" (European Central Bank, 2000). 
The paper is organised as follows: Section 2 discusses the evolution of inflation rate in transition to a market economy period, Section 3 estimates the impact of EU accession upon inflation rate in Central and South-Eastern Europe's states; Section 4 analyses the causes of inflation differential in Central and South-Eastern Europe's states; Section 5 presents concluding remark.

\section{The Implications of the Transition to a Market Economy upon the Inflation}

The majority of countries in transition from Central and Eastern Europe have struggled with a strong inflationary process, manifesting itself in the first years of transition as corrective inflation, following that persistent imbalance between supply and demand to change it into a structural inflation (Table 1).

The consumer price evolution in the transition economies from Central and Eastern Europe can be divided in four stages (ICEG European Center, 2002). In the first phase (until 1992) almost all of the countries have registered a corrective inflation associated with the liberalization of prices and of trade and the significant depreciation of the exchange rate.

Table 1. The average inflation rate in Central and Eastern European countries (\%, 1989-1999)

\begin{tabular}{llllllllllll}
\hline Country & $\mathbf{1 9 8 9}$ & $\mathbf{1 9 9 0}$ & $\mathbf{1 9 9 1}$ & $\mathbf{1 9 9 2}$ & $\mathbf{1 9 9 3}$ & $\mathbf{1 9 9 4}$ & $\mathbf{1 9 9 5}$ & $\mathbf{1 9 9 6}$ & $\mathbf{1 9 9 7}$ & $\mathbf{1 9 9 8}$ & $\mathbf{1 9 9 9}$ \\
\hline Czech & 1.4 & 9.7 & 52.0 & 11.1 & 20.8 & 9.9 & 9.6 & 8.9 & 8.4 & 10.6 & 2.1 \\
Republic & & & & & & & & & & & \\
Estonia & 6.1 & 23.1 & 210.5 & 1076.0 & 89.8 & 47.7 & 29.0 & 23.1 & 11.2 & 8.1 & 3.3 \\
Hungary & 17.0 & 28.9 & 35.0 & 23.0 & 22.5 & 18.8 & 28.2 & 23.6 & 18.3 & 14.3 & 10.0 \\
Latvia & 4.7 & 10.5 & 172.2 & 951.2 & 109.2 & 35.9 & 35.9 & 25.0 & 17.6 & 8.4 & 4.7 \\
Lithuania & 2.1 & 8.4 & 224.7 & 1020.5 & 410.4 & 72.1 & 39.6 & 24.6 & 8.9 & 5.1 & 0.8 \\
Poland & 251.1 & 585.8 & 70.3 & 43.0 & 35.3 & 32.2 & 27.8 & 19.9 & 14.9 & 11.8 & 7.3 \\
Slovakia & 2.3 & 10.8 & 61.2 & 10.0 & 23.2 & 13.4 & 9.9 & 5.8 & 6.1 & 6.7 & 10.6 \\
Slovenia & 1285.3 & 551.6 & 115.0 & 207.3 & 32.9 & 21.0 & 13.5 & 9.9 & 8.4 & 8.0 & 6.2 \\
\hline
\end{tabular}

Source: European Bank for Reconstruction and Development, http://www.ebrd.com/pages/research/economics/data/macro.shtml\#macro

But this liberalization was not complete, the weight of goods in the consumer basket whose prices are administered being included between $13 \%$ and $24 \%$ in the countries from Central and Eastern Europe. Of the prices administered, the liberalization of energy prices for households represents one of the most important tasks which had to be finished until the accession. Reininger (2000) analyses the evolution of the energy price in four acceding countries from Central and Eastern Europe: the Czech Republic, Poland, Hungary and Slovakia in the 1992-1999 period. His results shows us that the energy prices in the candidate countries have reached the level of those in the European Union for industrial consumers, while the prices charged for households were low even in the 1998-1999 period. The author concludes that major adjustments are necessary in order to reach the level of the EU economies. The adjustment of energy prices has had a significant impact upon the consumer price index in the acceding countries, because they hold approximately $15 \%$ in the consumer basket (Backé, Fidrmuc, Reininger \& Schardax, 2002).

The second period (1992/1993-1998) was marked by the decrease of the inflation rate at moderate levels. In the next stage, between the years 1998-2000, the inflationary process was strongly influenced by the crises in Asia and Russia, through the negative shock of demand (the decrease of external demand) and the positive shock of supply (the decrease of oil prices) which have tempered the inflation rate. In this period, the inflation rate has registered values with one or two numbers. The last price evolution stage which characterized these economies (from the beginning of the year 2001) was marked by a disinflationary process.

The registration of different inflation rates in the 1992-1998 period is due to the existence of macroeconomic imbalances in some economies and of the type of monetary and exchange policies adopted by each country. These countries have adopted, on different transition stages, different monetary policies, depending on the specific characteristics of each country. Despite all of these, we can observe a shift from monetary policy strategies based on the exchange rate, used, generally, at the beginning of the transition, to strategies based more on the inflation targeting, in a more advanced transition stage.

Another cause which has slowed down the disinflationary process was the high fiscal deficit due to the low level of income collection for the state budget and the unchanged maintenance of expenditure. The cover of the fiscal deficit through seigniorage has constituted the main inflationary source in some transition economies. 
The inflation rate divergence during the ongoing transition is explained by the economic analysts through differences between the level of economic development and the capacity to uphold the reforms necessary to become a market economy.

European Bank for Reconstruction and Development calculates nine reform indices: Large scale privatisation, Small scale privatisation, Enterprise restructuring, Price liberalisation, Trade \& Forex system, Competition Policy, Banking reform \& interest rate liberalisation, Securities markets \& non-bank financial institutions, Overall infrastructure reform. An index score equal to 1 indicates no reform relative of a "standard" planned economy, while the maximum score 4.3 corresponds to a well-functioning market economy (Staehr, 2003).

In the Baltic States, in 1991, inflation rate has registered values with 3 digits (172.2\%-224.7\%), while in 1992 inflation rate has accelerated to approximately 1000\%. Regarding reform indices, in 1991 in Estonia majority of indices has registered the value of 1, while in Latvia and Lithuania only Price liberalisation indicated a index score equal to 2.67, rest of indices being equal to 1 . In 1992 majority of indices scores has increased and in 1993 index of Price liberalisation was 4.33 in Estonia, Latvia and 4 in Lithuania. In this year inflation rate has decreased significant, following a disinflationary trend in the next years.

Hungary has registered in 1989 the index score of Price liberalisation of 2.67, Trade \& Forex system of 2, while the inflation rate was $17 \%$. The highest value of inflation rate was in $1991(35 \%)$; in this year, index score of Price liberalisation has indicated 4.33, Trade \& Forex system has indicated 4.

In Poland the reform has begun early, in 1989 Small scale privatisation and Price liberalisation has indicated a index score equal to 2, respective 2.33. In 1990 only one of the indices (Securities markets \& non-bank financial institutions) has indicated a score equal to 1 , justifying the high inflation rate $(585.8 \%)$ in this year. Disinflationary trend is correlated with the reform index score, these indices being above 2.67 in 1996. Small scale privatisation and Trade \& Forex system have registered maxim value -4.33 .

If in 1990 all the index equal to 1 in Slovakia, in 1991 the majority of the indices has increased with one, two or three; index score of Price liberalisation was 4. In this year inflation rate has increased by $50.4 \%$, in 1992 the inflation rate returning to value in 1990 .

In 1989 inflation rate in Slovenia was 1285.3\%, while the index score was above 2 for Small scale privatisation and Price liberalisation. In 1990 index of Securities markets \& non-bank financial institutions has increased to 2 and index of Price liberalisation has increased from 2.67 to 3.67 , imprinted the increase of consumer prices by 551.6\%. In 1993 the inflation rate has registered a significant decrease (from $207.3 \%$ to $32.9 \%$ ), due the high values of reform indices.

We remark the positive correlation between reform indices score and inflation rate in the first years of transition. Disinflationary process has begun when reform indices has registered high values, which means that structural reforms have had a significant impact upon the evolution of inflation rate in the transition period.

Therefore, the acceleration of inflation rate in 1991 in all countries is justified by beginning of reforms necessary to become a market economy.

In contrast with the transition countries we have the member states of the European Union, whose inflation rates maintained themselves at relatively low levels, which suggests the differences between a mature market economy and a forming one.

\section{The Inflationary Effects of Accession to the European Union}

The years prior the European Union accession were marked by a significant disinflationary process in most of the accession countries, seeing as price stability is one of the requirements to join the EU. The registered progress by the accession countries starting with 2001 were due to the favourable shocks in supplying (the decrease of oil prices) and the deceleration of foods prices, in some countries, but also due to the policies used to combat inflation. This signifies the importance of price stability as statutory objective of the central banks in each accession country. Even if the inflation tempered, it is a major preoccupation for the monetary authorities, the evolution of inflation being an indicator in the convergence evaluation with the euro area.

The statistic data (Table 2) show that the negative aspect of EU accession refers to the accentuated increase of inflation rate in accession year (2004), the highest inflation rate registering in Latvia (from $2.9 \%$ to $6.2 \%$ ), Poland (from $0.8 \%$ to $3.5 \%$ ), the Czech Republic (from $0.2 \%$ to $2.8 \%$ ), Lithuania (from $-1.1 \%$ to $1.2 \%$ ) and Hungary (from $4.7 \%$ to $6.8 \%$ ). The alignment of some prices to the consumer goods and services and of some taxes, imposed in the context of accession to the level of the old EU countries created objective inflationary pressures in the new member states. 
Table 2. The average inflation rate in Central and Eastern European countries (\%, 2000-2004)

\begin{tabular}{llllll}
\hline Country/Year & $\mathbf{2 0 0 0}$ & $\mathbf{2 0 0 1}$ & $\mathbf{2 0 0 2}$ & $\mathbf{2 0 0 3}$ & $\mathbf{2 0 0 4}$ \\
\hline Czech Republic & 4,0 & 4,7 & 1,8 & 0,2 & 2,8 \\
Estonia & 4,0 & 5,8 & 3,6 & 1,3 & 3,0 \\
Hungary & 9,8 & 9,2 & 5,3 & 4,7 & 6,8 \\
Latvia & 2,6 & 2,5 & 1,9 & 2,9 & 6,2 \\
Lithuania & 1,0 & 1,5 & 0,3 & $-1,1$ & 1,2 \\
Poland & 10,1 & 5,5 & 1,9 & 0,8 & 3,5 \\
Slovakia & 12,0 & 7,3 & 3,0 & 8,5 & 7,5 \\
Slovenia & 8,9 & 8,4 & 7,5 & 5,6 & 3,6 \\
\hline
\end{tabular}

Source: European Bank for Reconstruction and Development, http://www.ebrd.com/pages/research/economics/data/macro.shtml\#macro

The increasing of consumer prices in accession year has been determined by the adoption of the EU acquis and of some policies and mechanisms specific to the European Union. In this sense, the following six factors have been analysed:

1). Implementing the Common Agricultural Policy (CAP) represents one of the factors that affects consumer prices after accession. The changes of agricultural prices have influenced the food prices, whose weight in the consumer basket was approximately 16-20\%, the impact being stronger in Lithuania and Latvia where these had approximately $26 \%$ in the consumer basket. We must notice that prices of the agricultural products in the analysed countries were lower than the EU level. Prediction show that in the Czech Republic, Hungary, Poland, Slovakia, Slovenia the levels of compared agricultural prices were between half and three quarters of the EU average (Backé et al., 2002).

2). The necessity of excises alignment on the level of the those from the EU has determined a significant rising of excisable goods and services, exerting influences upon prices of Alcoholic beverages, tobacco; prices of Housing, water, electricity, gas and other fuels and prices of Transport. The contribution of these components of the HICP to annual inflation rate was different in EU countries from Central and South-Eastern Europe, differences that are explained on account of prices increase of these goods and services and of the weight in the consumer basket.

3). Another factor which has exercised influences upon consumer prices was Common Customs Policy, but its impact has been positive. The elimination of the customs duties applied to import of goods from the EU has offset the negative impact of the two factors mentioned above. The size of the positive effect varies from country to country, depending on the share of EU imports in total imports, in 2004 this being between $63.3 \%$ (Lithuania) to $81.3 \%$ (Slovenia).

4). The free movement of goods among the EU countries has determined the increase of competition, with an effect upon the price and quality of goods.

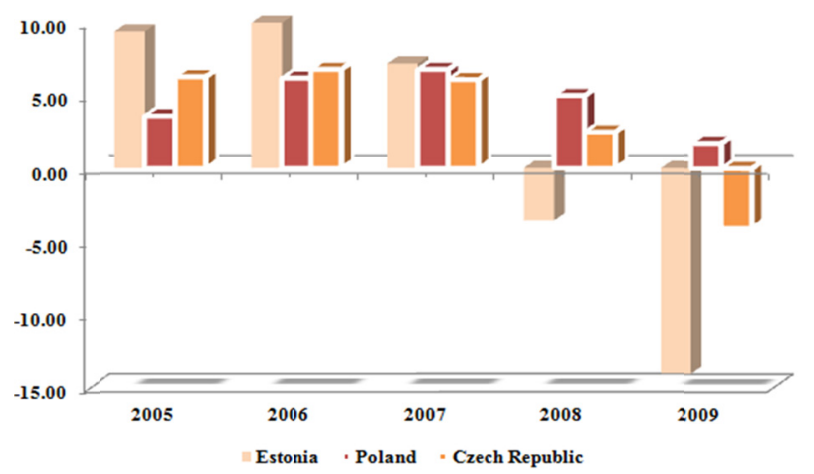

Figure 1. Real GDP in the Czech Republic, Estonia, Poland (2005-2009)

Source: Eurostat, http://epp.eurostat.ec.europa.eu/portal/page/portal/statistics/themes

5). Free movement of capital, another chapter in the EU acquis, promotes an efficient allocation of economies on 
a global level and a better diversity of financial risks. On this way, the capital account liberalization can lead to economic growth and social welfare (Altar, Albu, Dumitru \& Necula, apud Fisher, 1998).The rapid economic growth generated by the inflow of the EU funds created inflationary pressures upon internal demand. This process is reflected by the increasing of the inflation rate in Poland starting with 2007 (Office of the Committee for European Integration Department of Analyses and Strategies, 2008). The statistics data show that the analysed countries have registered significant increases of the real GDP after EU accession, until 2007, being an inflationary factor (Figure 1).

6). According to the Eurobarometer 62 from May 2005, European citizens perceive a negative role of the European Union in the development of the inflation rate, which means that the expected inflation has negatively influenced the inflation rate in 2004. Less than $35 \%$ from the citizens of the analysed countries consider that the European Union has a positive role upon inflation, the most pessimistic being the Czech (13\%) and the Polish $(11 \%)$.

The inflationary effects of the accession process in the Central and South-Eastern Europe countries have been on a short-run, but the catching process, in order to adopting the euro, has been on a long-run, leading to inflation differential between EU member states.

\section{The Causes of Inflation Differential in EU Member States from Central and South-Eastern Europe}

The inflation rate from the European Union countries does not converge to a common level. Numerous research have analysed the convergence of the inflation rate in the European Union and the causes of differential among them. The inflation differentials between EU countries are generated by five factors.

1). Maier (2004) analyses the inflationary consequences of price convergence of tradable goods in the accessing countries in 2004 and the future member states of European Union (Romania, Bulgaria, Turkey). Taking into consideration the prices differential of the tradable goods (they have $40 \%$ in consumer basket), the convergence of these prices is a source of inflation differential. When the price differential are hidden, there are the inflation differential. As a result of the convergence process of the price of tradable goods, the inflation in the new member states could be on average by $1.5-3.5 \%$ higher than in the euro area.

The price level convergence towards a common level is a prime source of inflation differential, because the price level in the member states varies from one country to another. The countries where the price level is lower by $20 \%$ than the euro area average are exposed to a rate of inflation higher by $1 \%$ over the euro area (Horváth \& Koprnická, 2008).

2). The real convergence, necessary for adopting the single currency, has a major impact upon the inflationary process, because the reduction of disparities in terms of GDP/capita is accompanied by price increase of services. The inflation differential between countries can be explained based on the Balassa-Samuelson effect, due to the lower development level in the accession countries vis-à-vis the euro area. Depending on the services weight in the consumer basket, the increase of their prices will have a higher or lower impact upon overall inflation. In the year 2009 the weight of services in the consumer basket in the analysed countries was between $25.33 \%$ (Lithuania) and 39.33\% (Malta). De Grauwe and Skudelny (2000) have estimated on the long-run the effects of the differential of productivity between the tradable sector and non-tradable sector upon inflation rate in EU member states, highlighting that the impact of a productivity shock upon inflation rate can be substantial, meaning an increase of $8 \%$ in the inflation differential.

$3)$. Another cause of inflation differential is given by the exchange rate. The impact of the exchange rate is reflected, firstly, on the import prices, then fuels the prices of tradable goods on the internal market and finally, the overall inflation. The biggest influence is exerted by currency fluctuations against the euro, given that the imports from the European Union have a significant share in the international trade of the member countries. The share of imports from European Union in the total of imports is approximately $60-80 \%$ in the analysed countries. But the fluctuations of the exchange rate depend on the type of exchange rate arrangement, therefore the inflation rate is not influenced by exchange rate variations in case of the Currency Board (Lithuania) or is influenced very little in case of other conventional fixed peg arrangements (Latvia). In case of floating (the Czech Republic, Poland), the variations of the Czech koruna and of the Polish zloty have a significant influence upon the inflation rate.

Honohan and Lane (2003), investigating the causes of divergent inflation rates among EMU member countries in the 1999-2001 period, highlight that, despite the common currency, the exchange rate fluctuations have had a substantial impact on changes in inflation rate and inflation differentials in EMU. This is explained by the different degree of exposure of member states to trade outside the euro area. The divergent inflation rates have 
coincided with convergence of price levels.

4). The rising of the oil price on the international market exerts pressure upon consumer prices, being another cause of inflation differential. The effect of oil price upon the inflation rate depends on the degree of dependence on oil import of that country. The influence of the oil price upon the inflation differentials can be explained through the weight of Housing, water, electricity, gas and other fuels and of Transport in the consumer basket, this varying in the year 2005 between 6.45\% (Cyprus) and 20.60\% (Slovakia), respectively 10.31 (Lithuania) and $17.78 \%$ (Cyprus).

5). Another factor that plays an important role in explaining of the inflation differential is different weight of goods and services in the consumer basket (Figure 2). Food and non - alcoholic beverages have a higher weight in the consumer basket in Latvia and Lithuania (approximately 27\%) in comparison with the other countries (approximately 18-20\%).

For example, the increase of food prices on the international market has a different impact upon inflation in the EU Member States, due to different weight of these goods in the consumer basket, leading, thus, to inflation differential.

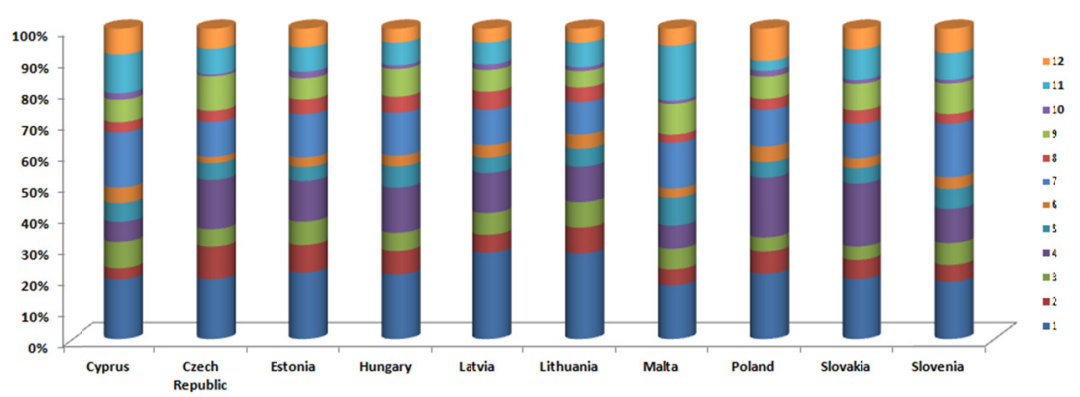

Figure 2. Weights of HICP components in EU Member States (2005)

Note: 1 - Food, non-alcoholic beverages, 2 - Alcoholic beverages, tobacco, 3 - Clothing and footwear, 4 Housing, water, electricity, gas and other fuels; 5 - Furnishings, household equipment and routine house maintenance, 6 - Health, 7 - Transport, 8 - Communication, 9 - Recreation and culture, 10 - Education, 11 Restaurants and hotels, 12 - Miscellaneous goods and services.

Source: European Central Bank, http://sdw.ecb.europa.eu/browse.do?node=2120778.

In the Czech Republic the alcoholic beverages and tobacco have a significant weight in the consumer basket $(10.5 \%)$, three times higher than in Cyprus, which means that harmonization of the legislation regarding excises has had a major impact upon the inflationary rate from the Czech Republic.

To show the divergence of the inflation rate, we have calculated the standard deviation for the 2004-2010 period in analysed countries. Figure 3 shows us the high inflation differentials in the year 2008, the main explanation for this being related to the oil price oscillations on the international market, which went up to the level of 85.9 euro/barrel in June. In the following months it has changed its evolution, in December the price of oil being 32.1 euro/barrel, signifying a drop by approximately $63 \%$ by the maximum level from June 2008 , as a result of improving the supply conditions. In the year 2009, this had an ascending trend caused by deepening economic crisis and decreasing demand. 


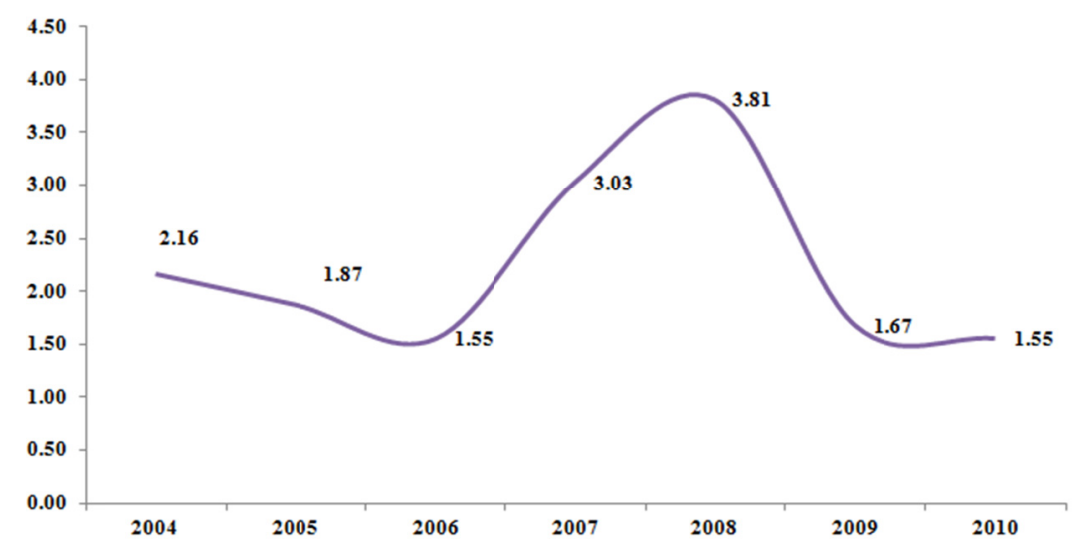

Figure 3. The evolution of standard deviation of inflation rate in EU Member States (\%, 2004-2010)

Source: Eurostat, http://epp.eurostat.ec.europa.eu/portal/page/portal/statistics/themes, authors' calculations

The high value of standard deviation from the year 2008 signifies differences between countries regarding the dependence on oil import, but also the rate exchange rate fluctuations. For example, in the year 2008, the Czech koruna and the Polish zloty were appreciating very much against the euro, the exchange rate diminishing by over $10 \%$, which means that it had a significant positive impact upon the imported inflation.

Also, the inflation differentials vis-à-vis the euro area highlight the process of inflation rates convergence which is supposed to follow the countries subjected to analysis.

Although the majority of EU member states register higher inflation rates than the euro area, there are some economies which reached very close to the euro area, in what concerns the price stability in the period 1997-2004 (Table 3).

Table 3. Inflation differential vis-à-vis the euro area $(\%, 1997-2010)$

\begin{tabular}{l|llll}
\hline Country/Year & \multicolumn{2}{|l}{$\mathbf{1 9 9 7 - 2 0 0 4}$} & \multicolumn{2}{l}{$\mathbf{2 0 0 5 - 2 0 1 0}$} \\
& Average & Standard deviation & Average & Standard deviation \\
\hline Cyprus & 0.88 & 1.14 & 0.18 & 0.53 \\
Czech Republic & 2.08 & 3.61 & 0.68 & 1.38 \\
Estonia & 2.93 & 3.07 & 3.2 & 2.85 \\
Hungary & 7.88 & 4.94 & 3.68 & 1.53 \\
Latvia & 1.93 & 2.33 & 6.39 & 3.61 \\
Lithuania & 0.61 & 3.88 & 3.48 & 2.8 \\
Malta & 0.91 & 0.98 & 0.44 & 1.17 \\
Poland & 5.04 & 5.29 & 0.82 & 1.74 \\
Slovakia & 5.83 & 2.78 & 0.74 & 0.84 \\
Slovenia & 5.18 & 1.84 & 1.02 & 0.88 \\
\hline
\end{tabular}

Source: Eurostat, http://epp.eurostat.ec.europa.eu/portal/page/portal/statistics/themes, authors' calculations

We remark a diminishment of inflation differentials in the 2005-2010 period, the Maastricht Treaty having a significant impact upon the inflation rate convergence, with the exception of the Baltic States. The rising of gap between the inflation rate in the Baltic States and the euro area can be explained on the basis of the exchange rate arrangements that characterises these states. Currency board arrangement (Estonia, Lithuania) or other conventional fixed peg arrangements (Latvia) assume the fixity of the exchange rate, respective its variations in a narrow margins of less than $\pm 1 \%$ around a central rate. This means the impossibility of the nominal appreciation of the national currency, the manifestation of the Balassa-Samuelson effect, which amplified after the EU accession, having consequences only on the inflation rate. Therefore, monetary policy strategy has an essential role in achieving price stability criterion.

\section{Conclusions}

Concluding, the countries which joined in 2004 have recorded significant reductions in the inflation rate before 
EU accession, which signifies the importance of price stability in accession countries. The impact of accession on the inflation rate was both positive (the introduction of the Common Customs Policy and the free movement of goods) and negative (the adoption of the Common Agricultural Policy, the harmonization of the structure and rates of indirect taxes, the free movement of capital and the expected inflation).

The statistical data shows us that inflation rates in European Union states members are not convergent, the causes are the following: the price level convergence, the manifestation of the Balassa-Samuelson effect, the exchange rate, the oil price shocks, the different weight of goods and services in the consumer basket. From the analyses we have done, we can notice that the exchange rate fluctuations, the dependence on oil import and the weight of Housing, water, electricity, gas and other fuels and of Transport in the consumer basket were the main causes of divergent inflation rates in EU member states from Central and South-Eastern Europe. Among the analysed factors, the impact of exchange rate depends on monetary policy strategies in the Member States, which means that monetary strategies heterogeneity explains inflation differentials in the European Union.

Also, the results highlights the diminishment of inflation differentials vis-à-vis the euro area after the accession, with the exception of the Baltic States. The explanation is given by the intensifying of the Balassa-Samuelson effect after accession and the impossibility of appreciation of the national currency in these countries, the impact being only on the inflation rate.

\section{References}

Altar, M., Albu, L., Dumitru, I., \& Necula, C. (2008). The impact of liberalization of capital account on the exchange rate and on Romanian economy competitiveness. The European Institute. Retrieved from http://www.ier.ro/documente/studiideimpactPaisIII_ro/Pais3_studiu_2_ro.pdf

Backé, P., Fidrmuc, J., Reininger, Th., \& Schardax, F. (2002). Price dynamics in Central and Eastern European EU accession countries. Oesterreichische Nationalbank. Retrieved from http://www.oenb.at/de/img/wp61_tcm14-6150.pdf

Brociner, A. (1999). Monetary Union, EMS, UEM, Single Currency. European Institute Publishing House: Iasi.

Czech National Bank. (2005). The Impact of the Czech Republic's accession to the European Union on consumer prices in the Czech Republic. Czech National Bank. Retrieved from www.cnb.cz/miranda2/export/sites/.../cr_eu_access_price_impacts.pdf

De Grauwe, P., \& Skudelny, F. (2000). Inflation and productivity differentials in EMU. Center for Economic Studies. Retrieved from https://irias.kuleuven.be/bitstream/123456789/121679/1/DPS0015.pdf

Doliak, M. (2004). Evaluation of the Common Agricultural Policy's impact on food prices following Slovakia's accession to the EU. BIATEC, XII(11), 2-7. Retrieved from http://www.nbs.sk/_img/Documents/BIATEC/BIA11_04/2_8.pdf

Duarte, M. (2003). The Euro and inflation divergence in Europe. Economic Quarterly, 89(3), 53-70. Retrieved from

http://www.richmondfed.org/publications/research/economic_quarterly/2003/summer/pdf/duartesummer03. pdf

Égert, B., Ritzberger-Gruenwald, D., \& Silgoner, M. A. (2004). Inflation differentials in Europe: past experience and future prospects. Monetary policy and the Economy, Q1, 47-72. Retrieved from http://www.oenb.at/en/img/mop_20041_inflation_differentials_tcm16-19277.pdf

Ehrlich, L. (2004). Differences in consumer price changes in the Baltic States subsequent to the accession to the European Union. Kroon \& Economy, 4, 28-34. Retrieved from http://www.eestipank.ee/sites/default/files/publication/en/Archive/kroon_economy/2004/_4_2.pdf

European Central Bank. (2000). The Eurosystem and the EU enlargement process. European Central Bank, Monthly Bulletin. Retrieved from http://www.ecb.int/pub/pdf/mobu/mb200002en.pdf

European Commission. (2005). Eurobarometer 62. Public opinion in the European Union. European Commission. Retrieved from http://ec.europa.eu/public_opinion/archives/eb/eb62/eb_62_en.pdf

Hofmann, B., \& Remsperger, H. (2005). Inflation differentials among the Euro Area Countries: potential causes

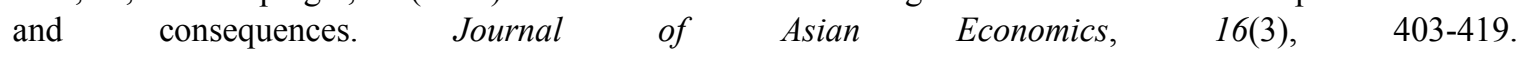
http://dx.doi.org/10.1016/j.asieco.2005.04.009

Honohan, P., \& Lane, P. (2003). Divergent inflation rates in EMU. Trinity Economics Papers. http://dx.doi.org/10.1111/1468-0327.00110_1 
Horváth, R., \& Koprnická, K. (2008). Inflation differentials in New EU Member States: empirical evidence. Finance a úvěr-Czech Journal of Economics and Finance, 58, 318-328. http://dx.doi.org/10.2139/ssrn.1311529

ICEG European Center. (2002). Inflation and disinflation in Central and Eastern Europe. Trend in the region. ICEG European Center. Retrieved from http://www.icegec-memo.hu/eng/publications/_docs/trends/trendsinflation.pdf

Licheron, J. (2006). Explaining inflation differentials in the euro area: dynamic panel data evidence. CREM-UMR CNRS 6211, University of Rennes 1. Retrieved from http://rief.univ-paris1.fr/Rennes2007/62-Licheron.pdf

Lommatzsch, K., \& Wozniak, P. (2006). Price level convergence and inflation in the EU- 8. (Background paper to the EFN-Euroframe report on "Convergence and integration of the New Member States to the Euro Area"). Retrieved from http://www.case.com.pl/plik--10070798.pdf

Maier, P. (2004). EMU enlargement, inflation and adjustment of tradable goods prices: what to expect? De Nederlandsche Bank NV. Retrieved from http://www.dnb.nl/binaries/Working\%20Paper\%20No\%2010-2004_tcm46-146667.pdf

National Bank of Poland. (2005). Annual report 2004. National Bank of Poland. Retrieved from http://www.nbp.pl/en/publikacje/r_roczny/rocznik2004_en.pdf

Office of the Committee for European Integration Department of Analyses and Strategies. (2008). 4 Years of Poland's Membership in the UE. Analysis of Social and Economic Benefits and Costs. Retrieved from $\mathrm{http}: / /$ ec.europa.eu/enlargement/pdf/5th_enlargement/facts_figures/4_years_poland_en.pdf

Roger, J. H. (2001). Price level convergence, relative prices and inflation in Europe, FRB International Finance Discussion Paper, 699. http://dx.doi.org/10.2139/ssrn.266505

Seman, J., \& Doliak, M. (2003). Accession to the European Union, the Common Agriculture Policy of the EU and its impact on food prices after Slovakia's accession. BIATEC, XI(7), 8-11. Retrieved from http://82.119.225.20/_img/Documents/BIATEC/BIA07_03/8_11.pdf.

Staehr, K. (2003). Reforms and economic growth in transition economies: Complementarity, sequencing and speed, Bank of Finland, Institute for Economies in Transition, BOFIT Discussion Paper, 1. http://dx.doi.org/10.2139/ssrn.1015454S 